\title{
War and migration in the White African tropics: Lauren St John's Rainbow's End
}

\author{
Richard Gehrmann \\ International Studies, University of Southern Queensland \\ Rachel Hammersley-Mather \\ Head, Project Development, SEED, Madagascar
}

\begin{abstract}
This paper explores voyage and migration in tropical Africa through Lauren St John's Rainbow's End, a memoir contributing to debates of white African identity that now include more contemporary renditions of identity in female self-reflective accounts differing markedly from masculine perspectives. In her coming-of-age memoir, St John chronicles her experiences of a privileged 1970s white Rhodesian society at war, and her gradual awareness of racial inequalities that transformed her into a white Zimbabwean. For her parents, voyage and migration take different paths. Her father migrated (with his family) to fight for a white Rhodesia, driven by masculine concerns. In contrast, St John's mother was an avid traveller who journeyed from the mundane world of tropical farm life to exotic locations in Europe and beyond, escaping both her deteriorating marriage and the dull world of the club, small town gossip and a narrow minded semi-colonial rural environment. St John's account of white settler identity and racial difference gives us insights into a day in the African tropics, and furthermore speaks to those in other settler countries such as Australia who are debating colonial history and identity, and who are often uncomfortable with aspects of their own settler past.
\end{abstract}

Keywords: White African, war, memory, Zimbabwe, Rhodesia, tropics

"In fact, I thought it was fantastic. My mother went travelling, my father went to war and I went to boarding school. It was the natural order of things" (St John, 2007, p. 154).

\section{Introduction}

The International Day of the Tropics celebrates the significance of the tropical zone, something that initially might seem to be far removed from Britain, the United States, or 
indeed, from most of Australia. The tropics clearly have importance for those who live in this zone, but it also has meaning for those who once lived there and for whom the tropics constitutes part of their geographical imaginary. Unlike expatriates or travellers whose tropical experiences have been those of the sojourner or the transient, migrants who have voyaged and left the tropics have an opportunity to recall a deeper sense of place, and can therefore address and understand deeper experiences that shaped them. An International Day calls us to celebrate and raise awareness, capturing our imagination, but for those migrants whose origins and upbringing link them to the tropics, this one day can be an everyday of a remembered past. And even if the migrant or voyager has put the tropics of the past aside, a memoir of tropical childhood can provide a site of renewed engagement - in this case with a tropical space implicated in war. This is significant not only to the author, but also to the reader, who is given the opportunity to vicariously experience, and perhaps understand, another time and place that might also have bearing on other settler-colonial histories.

Successful British children's writer and journalist Lauren St John's Rainbow's End: A Memoir of Childhood, War and an African Farm takes the form of a coming-of-age memoir of family life and growing up in the tropics in what was then Rhodesia (since 1980 named Zimbabwe) during the last years of white minority rule. Erica Bleeg notes of recent white African memoirs that they "often depict the guns and beer culture of whites behaving badly" (2007, p. 168), and this assessment is certainly validated here. While war, coming of age and understanding racism all underpin the memoir, this essay addresses Rainbow's End in the context of journeys and migrations in tropical Africa, while eliciting differences between feminine and masculine perspectives in white African memoir.

Lauren's parents embark on personal journeys: in the case of her father migrating to a war zone, a journey that reflects masculine concerns; while for her mother, the mindless narrow world of small town Rhodesia is a place she wishes to escape from, first to the metropolitan pleasures of Cape Town before embarking on adventures outside of Africa. Lauren's journeys are at first less physically geographical, as through her idyllic childhood she develops social, sexual and racial awareness, pre-empting her geographical voyage of emigration from the tropical world. However, before further analysis of these journeys, it is necessary to examine the social environment the author grew up in, and consider the complexity of white African identity.

\section{Tropical peripheries}

Zimbabwe occupies the intellectual and physical frontiers of white Africa. Located to the north of the Limpopo River, a river just above the meridian of the Tropic of Capricorn, Zimbabwe is geographically in the tropics. Superimposed above the equator onto a map of Southeast Asia Zimbabwe would cover the northern two thirds of Laos, and if superimposed on a map of Australia, it would extend across north Queensland from the latitude of Port Douglas down to Sarina. Just as northern Queensland represents the less civilised frontiers of Australia, Zimbabwe constitutes the outer periphery of the southern white African region, far removed from the more sophisticated high veldt conurbations of Johannesburg and Pretoria, or urban 
Cape Town, the mother city of white South Africa with its Mediterranean climatic zone and cosmopolitan identity. These southern spaces represent civilisation and sophistication for white Africa. In contrast Zimbabwe was a tropical frontier region in the nineteenth century colonial era (St John, 2007, pp. 34-35), with the image of the pioneering bush settler being central to ideological constructions of white identity. Under lan Smith's white minority rule (1965-80) as Rhodesia it represented the last outpost of secure white 'civilization' confronting what was seen as unsettling black African nationalist 'barbarism'. Such binary opposites were often explicated in terms of global anti-communism, the merits of Western culture, or of structured law-based government; but beneath these layers existed a worldview predominantly associated with race-based constructions of white superiority (White, 2015, pp. 198-199).

This liminal border zone of the tropical rural frontier is the setting for Lauren St John's memoir of her childhood. Yet while the story is located in Africa, the imagery of its tropical world and her relaxed childhood, resonate with metaphors not dissimilar to those of the rural Australian tropics. Small-town country and provincial issues, self-sufficient but inward looking communities, parochial activities, farm life and an ever present abundant wilderness impact on Lauren St John's world, a world where she grows up surrounded by the luxuriant growth of tropical gardens, "in direct communion with nature" and wildlife that ranged from birds to crocodiles (St John, 2007, pp. 116 - 117). This natural world is not entirely safe, and is one where a moment's inattention at a braai (barbecue) can lead to being swept down river with the risk of drowning or being eaten by crocodiles (St John, 2007, p. 47). Such tales of the junction between the civilized and the untamed may well resonate with those familiar with rural north Queensland.

The experiences revealed here are particularly apposite for other settler countries in the tropics, and it allows an Australian audience to observe the former world of some of the white African migrants who now live in Australia, permitting us to attempt to understand aspects of their complex and varied life experiences and identities. As the works by Louw and Mersham (2001), by Lucas, Jamali, and Edgar (2011) and Arnold (2011) have demonstrated, Australia became home to increasing numbers of white African migrants, ranging from business executives such as Robert Holmes à Court to writers such as J.M. Coetzee and Bryce Courtenay. Whether South African or Zimbabwean, white Africans have advantages that other immigrants to Australia lack, as their familiarity with the still-dominant Anglo-Australian culture makes post-migration settlement easier. Australia and southern Africa are components of the former British settler colonial world and share common historical structures, as Denoon (1983) has shown; but there are also differences. The legacy of conquest meant that white Africans lived uncertain lives of minority privilege, outnumbered by the ever present black Africans they had displaced, an existence that differed from the more relaxed white Australian settlement experience shaped and made secure by domination of the indigenous Australians.

\section{White African writing and identity}


Since the conquest of indigenous Shona and Ndebele states in the 1890s, the small white population has exercised a disproportionate influence in Zimbabwe. British colonial structures that allowed a degree of self-government by minority whites were overturned in 1965 with Prime Minister lan Smith's unilateral declaration of independence from Great Britain. African nationalist movements responded with the Second Chimurenga (War of Independence), known to whites as the Rhodesian Bush War. This increasingly bitter conflict formed a backdrop to Lauren St John's early life experiences. White political control ended in 1980 with the inauguration of Robert Mugabe's black majority government (accompanied by the culturally challenging and dynamic Pan-Africanist reggae music rhythms of Bob Marley) but a significant number of whites stayed on and became Zimbabwean. They occupied key roles in commercial farming and business until the collapse of the economy and expropriation of whiteowned farms in the early part of the twenty-first century as Mugabe's increasingly despotic regime made white Zimbabweans a scapegoat in his campaign against the Movement for Democratic Change.

The works of many white African writers contribute to an emerging genre that both reflects and shapes white African identity, yet such identity is implicitly tied to a past of racial division and inequality, and sometimes also to an uneasy attempt to romanticise the era of white rule and "forgive themselves and their forefathers for their actions and history" (Pilossof, 2009, p. 636). This is clearly articulated by Paul Williams (2013) who reflects on his own complicity in the past racism that often appears to be forgotten by sometimes sentimental writers who recreate the idea of an idealised Rhodesian past that contrasts with the corruption, insecurity and misgovernment characterising early twenty-first century Zimbabwe. Many white Africans have helped oppose the authoritarianism of Robert Mugabe's dictatorship, but this should not conceal the past era of white minority rule, as Tony Simoes da Silva (2011) has noted. While as a former member of the white minority community Lauren St John was part of the small elite that dominated the country until 1980, it is difficult to hold her responsible for that which as a child she could not consent to be part of. Her child status absolves the writer from complicity in the white regime, a status not shared by former soldier-authors such as MooreKing (White man, Black War, 1998), Godwin (Mukiwa: A White Boy in Africa, 1997) Cocks (Fireforce, 1997), Wylie (Dead Leaves, 2002) or Williams (Soldier Blue, 2008). Gender divides white African memoir - successful and widely read accounts by women such as Fuller (Don't Let's Go To The Dogs Tonight, 2002) and Lauren St John tend to reflect coming-of-age experiences while accounts by men are more likely to be structured as the soldier's memoir of the Rhodesian Bush War, often reifying "male-connoted nostalgic memories of white Rhodesia" (De Mul, 2009, p. 47), or focusing on the moral challenges of conflict, and adjustment, to a peacetime Zimbabwe. Despite her lack of complicity in the upholding the Rhodesian regime, Lauren St John's memoir contributes to the discourse of white identity politics for white Africans, and adds to the corpus of writing associated with the sometimes problematic white African settler narrative.

Rainbow's End is also an exploration of Rhodesian and white African identity. Along with many other white Africans the author has experienced a transition and shifting of identity from British colonial settler subject, to Rhodesian, to white Zimbabwean, white African and then expatriate. 
As Peter Godwin and lan Hancock have argued, Rhodesian identity was short lived and only constructed during the 1950s, 1960s and 1970s, and even at the height of white Rhodesia only 40 percent of white Rhodesians were born in the country, with a further 27 percent born in other African countries (1995, p. 16). As a culture that granted membership on the basis of skin pigmentation (White, 2015, pp. 30-32), the identity of the white Rhodesian was one that was quite easy for any light skinned person to assume, and could also provide refuge for a Polish Jew hiding from the legacy of the Holocaust (Gehrmann, 2013). At their peak only representing $6.3 \%$ of the population (Caute, 1983, p. 29), despite being predominantly urban, the white Rhodesians saw themselves as pioneers (Godwin and Hancock, 1995, p. 20), people on the borderlands between the untamed wild Africa and hundreds of years of European settlement in South Africa.

Lauren St John's own family draws on Rhodesian identity and her family's history of their settlement in Africa from 1820 onwards (2007, pp. 58-59). Yet the history of conquest, racial policies and domination of African majority populations makes white African identity one of ambivalence. This is in marked contrast to the American or British practice of considering anyone who becomes a citizen as American or British, in Africa whites remain European outsiders (St John, 2007, p. 249). The defeat of white Rhodesia destroys Lauren's Rhodesian self: "Now my identity was gone, and the shock was overwhelming" (St John, 2007, p. 192). This loss of identity could be overcome by becoming Zimbabwean, and Perlez (1989) records how even white Rhodesians such as Bruce Moore-King who had fought in the war were to cherish their post-war welcome to a new Zimbabwe. Yet the uncertainty of identity contributes to the need to migrate and voyage.

\section{Voyages: Lauren}

Like her mother, Lauren was born in Rhodesia, but spent a year as a child living in Cape Town, South Africa. In the absence of longed for black stallions she had a kitten that helped to ease her loneliness, but it failed to shut out the ever-growing tension between her parents in the "dreary mundanity" of life in Cape Town (St John, 2007, p. 10). Rhodesian to their souls, Lauren's family - including a baby sister, Lisa, born in Cape Town - returned to live at Giant Estate in Gadzema in 1975, her father taking responsibility of a farm with 1,400 acres of maize, 500 acres of cotton, and 3,200 cattle (St John, 2007, p. 13).

Perhaps emanating a child's idealism, Lauren reflects on her adventures on Giant Estate with an apparent romanticism; a childhood spent "secure in the force-field" of her parents' love (St John, 2007, p. 46). She was seemingly oblivious to the racial tensions between the African ethnic groups and whites and, as only children can be, is innocent in her racist definitions. For example, included in her list of "Accepted Facts about Africans" were "if you spoiled them, they got cheeky", "they were good at singing and dancing", "they had very virtuous babies" and that their "lack of motivation and tendency to idleness" were caused by the illness lent by worms and tropical disease (St John, 2007, pp. 23-24). This, along with a difference in soap brand preferences, was the level of racial knowledge Lauren had until the effects of the war reshaped her own life. 
In January 1976 at age nine, Lauren was sent off to boarding school; seemingly a safer existence than the farms in the war zones if it were not for the cruel, heavy-handed teachers (St John, 2007, pp. 52-54). Her boarding school stories are likely to evoke poignant memories for many Australians of a similar age who grew up on the land and were sent away for schooling, not just in complaints of the teaching staff and "nauseating" fish and chips, but in the games of marbles and scoffing artificially flavoured treats without parents around to prevent such delightful gluttony (St John, 2007, p. 56). It was at boarding school that Lauren began to exhibit her pride in being Rhodesian, her school books covered in stickers with jingoistic slogans such as "RHODESIA IS SUPER". Alongside these were messages such as "LOOSE TALK COSTS LIVES", and it was at boarding school that, alongside her carefree existence, she began to understand "the deadly business of war" (St John, 2007, p. 57).

To Lauren, the war began "in earnest" when a classmate accidentally shot himself with a loaded rifle that lay on a rug beside his bed (St John, 2007, p. 76). Despite her father's zest for the escalation of the war and his lengthy absences, Lauren was not profoundly affected by the fighting until the death of her class mate, Bruce Forrester (St John, 2007, pp. 103-104). Bruce was a shy boy who loved wildlife, falcons and ecology, and sat next to Lauren in class. His 1978 murder - along with that of his father, friend and grandmother at a terrorist attack at Rainbow's End farm - stunned Lauren and her family. Perhaps for the first time, Lauren understood loss: "The previous evening, Bruce had been alive... (he) had been due to start school with us in the morning. Due to have a future and a life" (St John, 2007, p. 103). When the pictures of the dead Forrester family appeared in the Herald, war was not a game anymore.

At the time of Bruce's death, Lauren would not have understood the profound effect the loss of his family would have on her life. Within months, and despite her mother's protests, Lauren's father had secured a manager's position on Rainbow's End, which was more than a farm; it had a game reserve complete with ostriches named Cheeky and Beaky, and a giraffe, Jenny (St John, 2007, pp. 111 -112). Adventure began to combine with adolescent experiences and emotional turmoil, but the grim reality of Rainbow's End - and indeed Rhodesia - seeped ever-closer to the surface for Lauren. Decorating her bedroom with iconic 1970s posters of pop singer Olivia Newton-John and the Marlboro Man, she noticed a mark on the cupboard door: "a maroon punctuation mark of dried blood... a kind of comma, like life interrupted" (St John, 2007, p. 113). When Lauren tried to wash it away it reconstituted and, as the birds outside were singing and a magnificent day went on, Bruce Forrester's blood was again being mopped up, now by his former school friend, the next child-occupant of this innocuous site in the war zone.

Lauren noted that she feels her life can be divided in two: before Rainbow's End and after it. While she vividly paints Rainbow's End as a child's paradise, it was here that she developed a true awareness of her family and her country. Still enamoured of the war and its opportunities for her to display her heroism, Lauren comments throughout her memoir of her desire to be a boy, or at least to resonate and replicate masculine tendencies. Knowing her husband perceived Lauren to be "as good as any boy", Lauren's mother, May, strove to mould her 
second daughter Lisa into "a beauty pageant winner" (St John, 2007, p. 153). Meanwhile, in her adolescence Lauren "was secretly confident that even without training" she would save the day, and constantly looked for ways that she could replicate her father's innate bravery (St John, 2007, p. 148).

Behind her unsupervised freedom on Rainbow's End, her cherished role as farm vet and her python Samantha, she began to see the cracks in her parents' relationship and in the perceived truths of white Rhodesia. Between her frequent sojourns overseas, Lauren's mother had her own apartment in Salisbury (now Harare), and even explored the beaches and tropical rainforests of Queensland so the family could migrate and start afresh (St John, 2007, p. 184). Upon May's return, Lauren's father declared that he had no intention of leaving Africa, or of remaining married. Despite attempts to make the marriage work, her father's wandering eye ('Mom said coldly: "If you knew the truth about him, you'd never speak to him again"') coupled with her mother's Bohemian volatility meant that the marriage failed around the same time the white Rhodesian regime also collapsed under the pressure of African nationalist guerrilla attacks and international pressure (St John, 2007, p. 199).

With the war over in 1980 and Mugabe in power, Lauren sensed that the glue that had bound her family and Rhodesia together - "through thick and thin" - had come undone (St John, 2007, p. 190). Her experiences with the African population had previously been from her position of white privilege and the sudden arrival of African children into her school saw Lauren unnerved: "they were tougher than us, and smarter in all the ways that mattered" (St John, 2007, p. 207). Gradually, she became aware of the toxic racism and injustice of her previous life of white privilege. Upon finishing school, and with Rhodesia as she knew it ended, Lauren left Rainbow's End and Zimbabwe, "as fast as I could because there is no other way to leave a place that has come to embody all your childish dreams and many of your nightmares - or a country where most of your truths have been shown to be lies" (St John, 2007, p. 107). Lauren went to Cape Town with her mother and sister, before realising that at seventeen, she had to go out into the world alone. After spending a year in England as a veterinary nurse, she returned to Zimbabwe to study journalism. It was then that she began to find herself, and to celebrate the rich diversity of her exciting new multiracial country.

\section{Migration: Errol}

Migration and voyages are also central to Lauren's parents. Errol, the author's father was not born in Rhodesia but like twenty-one percent of white Rhodesians (Godwin and Hancock, 1995, p. 16) was South African, and for him becoming part of the Rhodesian tropical world had been a conscious act of migration linked to his masculine desire for adventure and military experience. Growing up as an English speaker in an Afrikaans-dominated white South African society, he sidestepped his South African national service by taking an alternative, more adventurous, option advertised in the local newspaper, and travelled north to Rhodesia to complete his military service in the Rhodesian army (St John, 2007, p. 4). With his South African family history deeply embedded in his personal identity, Errol was influenced by colonial notions of his forebears' adventurous pioneering spirit, which shaped his decision to 
migrate north across the Limpopo River. Errol was confident and took risks, laughing and relishing the adrenaline high of going out alone at night to confront likely guerrillas (St John, 2007 , p. 168) with the same testosterone fuelled enthusiasm with which he handled toxic farm chemicals with bare hands and arms, unlike his African workers "correctly attired in gloves, protective clothing and gumboots" (St John, 2007, p. 151). As the descendant of several soldiers and having parents who both undertook military service during the Second World War (St John, 2007, p. 77), he had accepted the values implied by military life - and also enjoyed the adrenaline rush of being a soldier. Such feelings were to inform his decision to migrate to the war zone with his family.

After returning to Cape Town for only a year, her father migrated north again to Rhodesia to go to war because of masculine concerns. He knew that by staying in South Africa, others believed he was avoiding a conflict that had become his own - "I couldn't stand people saying I ran away from the War" (St John, 2007, p. 3). As the guerrilla war intensified in the mid1970s, many white Rhodesians had emigrated to a safer South Africa, and Errol felt offended by the idea that he would be seen as a coward who fled Rhodesia for the southern sanctuary. After being offered a job in Rhodesia in 1975, one of his first acts on arrival was to join the security forces as a part-time soldier on duty seven days a month. As the level of fighting increased in 1976, he joined Grey's Scouts, a reconnaissance unit that required him to undertake twenty-eight day service on, and twenty-eight day service off - a commitment hardly conducive to stable family life. Although military service was compulsory in white-ruled Rhodesia, in keeping with his decision to migrate to war, Errol was an enthusiastic volunteer trying to recapture his youthful military self as he "rebelled against the shackles of domesticity" (St John, 2007, p. 179).

As she became older Lauren was told her father's war stories, and the detritus of war that was an everyday part of his life became part of hers, as when her father casually told her that their knife with a bone handle was a war trophy taken from the body of a dead enemy (St John, 2007 , p. 136). Their discussions could be far from reassuring. The war intruded on routine conversations as Errol educated his elevan year-old while driving off on a father-daughter fishing weekend.

'Dad said 'D'you know how to look for landmines, do you?'

'What?' I stalled. ...

'Don't say "what". Why don't you listen to me when I talk? He sucked in his breath in sudden fury and released it in a pressure cooker hiss. 'I saaaaid, do you know how to look for landmines?' ... I shook my head quickly, and tears pricked the back of my eyes.

'Well, the main thing is, you look for new diggings or disturbed earth. Anything that looks sort of like unnatural, like it's not supposed to be there.'

'Are the landmines big?' I imagined them to be like trip wires, snaking under the road.

'You know, not really. The gooks even hide them in pieces of cow dung.' 
'Then how do you know if your wheel is going to go over them?'

'It's sort of like the law of averages. Sooner or later, somebody is going to set one off.'

'But if they're that small, how are we meant to see them?'

His mouth twitched. 'Ag, if it's done professionally, you've got no chance really.' (St John, 2007, p. 84).

Errol's decision to migrate towards war was motivated by his own masculine concerns, but of course influenced his entire family when he bought them back into the war zone with him. The trauma of war remained an ever present part of Rainbow's End, and the book's prologue forensically details the guerrilla attack on Rainbow's End, the very farmhouse that Lauren was to live in. Her detailed journalistic description of the killing and wounding of the previous inhabitants, the blood spattered walls, and the smell of death situate her memoir. Wylie (himself a former soldier in this war) may have described Lauren's account as "a poised and understated reminiscence of a childhood astonishingly lived in intense happiness even in the middle of the war" (2007, p. 161), but the experience of childhood in war is an enduring theme of her early life and encroaches on the domestic sphere with not an evening passing without her father stripping and cleaning his guns after dinner (St John, 2007, p. 148). Houses are surrounded by security fences, news reports of deaths and wounding are a daily occurrence, and soldiers driving through towns in armoured vehicles and relaxing in troop canteens shape her juvenile understanding that she was living in "a Nation at War" (St John, 2007, p. 76). Errol sends Lauren to boarding school - parents knew that life on farms was far too dangerous and the risk of guerrilla attacks made travel to and from school problematic (but parents could also enjoy the benefits of a life of servants and a childfree adult existence). Her father's frequent absences on military duty coincided with the arrival of an unknown intruder in the yard whom her mother subsequently shoots and wounds, the legacy of bloody footprints on the paving stones providing motivation for her mother to flee both the farm and her husband for the sanctuary of the city (St John, 2007, pp. 180-181).

Over time there is a migration away from domesticity, marital fidelity and social convention, as Errol becomes increasingly careless of the impact of his liaisons on his family. Lauren's father thinks of himself as the social inferior to others around him and it seems possible that this sense of inferiority is compensated for by his military service, as fighting is a socially valued activity at which he can excel.

There is yet another voyage taken by Lauren's family. This is the voyage away from the security of a formed family, a journey commissioned by her parents' incompatibility and her father's infidelity. After the war is over the threat of violence and fear is again imposed on their family as a consequence of Errol's philandering ("Another husband is coming to beat him up") as her mother, incoherent and terrified, warns her: "Carl B is on his way over. Anything could happen. You've got to get away from here." (St John, 2007, p. 254). In a society of hypocrisy and double standards, where women were the sluts who led men astray (St John, 2007, p. 204), Errol's belief that decent women don't sit at the bar with the men (St John, 2007, p. 179) evokes unpleasant memories of sexist values and gender divisions in Australia of the 1970s. 


\section{Voyages: May}

Voyages of a different nature were to occupy her mother. Lauren depicts her mother May as being attractive, fashionable and ever-determined to maintain the appropriate standards of beauty expected by middle-class Rhodesian women who inhabit a world sometimes reminiscent of Queensland in the Bjelke-Petersen government era of the late 60 s to 80 s. "The privileged lifestyle of a white woman was also circumscribed by explicit or subtle reminders that she lived - however willingly - in a male world" (Godwin \& Hancock, 1995, pp. 30 - 31). Despite working hard to make her home aesthetically pleasing and assisting her husband, she "never left the house without doing her make-up, curling her hair and putting on her best dresses and she always looked amazing" (St John, 2007, p. 27) even when just visiting the local town for Saturday shopping. May's glamour made other wives nervous and jealous of her, and Errol resented her lack of 'decency' when she did not include herself in the wives' clique on the veranda, but sat with the men at the bar (St John, 2007, p. $100 \&$ p. 179).

Once Lauren was off to boarding school, May became an avid traveller, voyaging away from the monotonous humdrum farm life and vindictive community gossip, to exotic locations such as the Himalayas, Austria and Bangkok. When at home she "floated round the garden like some Hollywood star from the Golden Era...wearing sunglasses and a sarong and reading $A$ Passage to India" (St John, 2007, p. 152). If she did enter the kitchen, it was to make a recipe she found on her travels: "a delicious Canadian carrot cake or Bumi Cheesecake" (St John, 2007 , p. 129). She tried to make the house reflect her love for the exotic, with upholstery of Japanese prints and coffee-table books about Matisse, Van Gogh and the ancient Egyptians. The worsening security situation and a declining marriage saw her escape to the city. While living in Salisbury and working at an accountancy firm, May had a flat that was "dusky-rose and faux Moroccan" (St John, 2007, p. 181); indeed, she seemed to try to remove herself from the stereotypes of rural Rhodesia and recreate herself as a free-spirited Bohemian.

Even so, it is evident throughout Rainbow's End that May was committed to her family and to her husband. On their re-emigration to Rhodesia from South Africa, Lauren said "Mom loved Cape Town but loved Dad more" (St John, 2007, p. 13) and even later, despite his extramarital affairs, she declined a marriage proposal from a young American because "she was only in love with Dad" (St John, 2007, p. 181). Still, May did not understand Errol's fury, when, on their first international family holiday in Europe, she and Lisa travelled on to England while Lauren and Errol had to return to the farm because restrictions meant Lauren's Rhodesian passport would not have allowed her to enter the United Kingdom (St John, 2007, pp. 153154). "Travelling had become like a drug to her, and she didn't always care how it happened, so long as it did happen" (St John, 2007, p. 154). May's discontent with her life in Rhodesia coincided with the 1970s era of women's liberation demands for greater equality and freedom. However, it seemed for May that the women's movement did not reach Rhodesia - two hours ahead of Britain's Greenwich Mean Time but 10 years behind - during Lauren's childhood, and so May searched for something else. She was an escape artist, "even though she hadn't managed to escape this - a life she hadn't wanted" (St John, 2007, p. 237). 


\section{Conclusion: Ex Africa}

Towards the closing stages of Rainbow's End, Lauren's mother takes off once again in search of escape, in this case flying to Queensland where she proposes to relocate her family following Zimbabwe's independence (St John, 2007, p. 184). This planned migration does not take place, but Lauren St John's memoir eventually concludes with another voyage, on this occasion the voyage away first of herself, and ultimately, by almost all the white African community of Zimbabwe. Immediately after independence many whites start leaving for South Africa and Britain (St John, 2007, p. 189), although others were to delay for two decades until the farm seizures of the early twenty-first century.

Today, in common with many other less skilled global population groups, white Africans increasingly occupy a world of dispersion, resettlement, expulsion and diaspora. Despite the obvious benefits of cultural capital, education and white privilege, diaspora can be challenging and traumatic. Of course, there was also a trauma for black Africans, a trauma that began with earlier white migration to Africa in colonial times, but this trauma is not always remembered by all twenty-first century white Africans.

A memoir like Rainbow's End serves a function for its author as an often cathartic reimagining and reliving of past trauma, and of voyages to and from tropical Africa. In terms of the study of colonial histories and identity formation, it provides a female-centric perspective of a settlercolonial African war in contrast to male narratives focussing on wartime combat. This memoir also allows us as readers to spend a day in the tropics of the past, the world that was once the everyday experience of thousands of people who migrated from tropical Africa to Australia, and who, by their lack of visual physical difference, do not stand out from white AngloEuropean Australians. For many of them, an international day of the tropics could be moment to pause and to remember an experience of living in a startlingly different world of racial privilege and hierarchy.

White Africans increasingly become migrants when faced with a loss of identity and reduced opportunities in an independent Africa, and they journey on to the United Kingdom, the United States, New Zealand or Australia. On arrival they bring with them a variety of past experiences that in some way are strangely familiar, being similar to the experiences of many Australians. In other ways, the experiences of racism and conflict are startlingly different and it is hard not to condemn their past existences as members of a privileged settler-colonial white elite. However, such criticism should perhaps not be too self-righteous, as the social conditioning and experiences that contribute to their new hybrid identities might have been that of any Anglo-European Australian had their forebears, like Lauren St John's forebears, by chance migrated in an earlier century from Europe to Africa, rather than to Australia.

\section{References}

Arnold, P.C. (2011). A unique migration: South African doctors fleeing to Australia. Edgecliff, Australia: CreateSpace. 
Bleeg, E. (2007). The country they lost. The lowa Review, 37(3), 168-173.

Cocks, C. (1997). Fireforce: One man's war in the Rhodesian Light Infantry. Roodepoort, South Africa: Covos-Day.

Caute, D. (1983). Under the skin: The death of white Rhodesia. Evanstown, IL: Northwestern University Press.

De Mul, S. (2009). Doris Lessing, feminism and the representation of Zimbabwe. European Journal of Women's Studies 16(1), 33-51.

Denoon, D. (1983). Settler capitalism: The dynamics of dependent development in the southern hemisphere. Oxford, United Kingdom: Clarendon Press.

Fuller, A. (2002) Don't lets go to the dogs tonight: An African childhood. London, United Kingdom: Picador.

Gehrmann, R (2013). A white African experience of identity, survival and Holocaust memory. Australian Journal of Jewish Studies 27, 193-206.

Godwin, P. (1997). Mukiwa: A white boy in Africa. London, United Kingdom: Picador.

Godwin, P. \& Hancock, I. (1995). Rhodesians never die; The impact of war and political change on white Rhodesia, c. 1970 - 1980. Harare, Zimbabwe: Baobab Books.

Louw, E. \& Mersham, G. (2001). Packing for Perth: The growth of a southern African diaspora. Asian and Pacific Migration Journal 10(2), 303-333.

Lucas, D., Jamali, M. \& Edgar, B. (2011). Zimbabwe's exodus to Australia, In African Studies Association of Australasia and the Pacific Conference 2011 (pp. 1-22). Adelaide, Australia: Flinders University. The African Studies Association of Australasia and the Pacific, Retrieved from: http://afsaap.org.au/assets/Lucas_Jamali_Edgar.pdf

Moore-King, B. (1998). White man, Black war. Harare, Zimbabwe: Baobab Books.

Perlez, J. (1989, January 13). Harare journal; Sergeant's war story: The shame of the whites. New York Times. Retrieved from http://www.nytimes.com/1989/01/13/world/harare-journalsergeant-s-war-story-the-shame-of-the-whites.html

Pilossof, R. (2009). The unbearable whiteness of being: Land, race and belonging in the memoirs of white Zimbabweans. South African Historical Journal, 61(3), 621-638.

Simoes da Silva, T. (2011). Longing, belonging, and self-making in white Zimbabwean life writing: Peter Godwin's When a Crocodile Eats the Sun. LiNQ, 38. Retrieved from: http://www.linqjournal.com/past-issues/volume-38-generations/longing-belonging-and-selfmaking-in-white-zimbabwean-life-writing-peter-godwins-when-a-crocodile-eats-the-sun/

St John, L. (2007). Rainbow's end: A memoir of childhood, war and an African farm. London, United Kingdom: Penguin.

White, L. (2015). Unpopular sovereignty: Rhodesian independence and African decolonisation. Chicago, IL: University of Chicago Press.

Williams, P. (2008). Soldier blue. Claremont, United Kingdom: David Phillip.

Williams, P. (2013). Writing a memoir of self-erasure: A practice-led exploration of constructing and deconstructing the coloniser-who-refuses. Text, 17(1). Retrieved from: http://www.textjournal.com.au/april13/williams.htm

Wylie, D. (2002). Dead leaves: Two years in the Rhodesian war. Pietermaritzburg, South Africa: University of Natal.

Wylie, D. (2007). The schizophrenias of truth telling in contemporary Zimbabwe. English Studies in Africa, 50(2), 151-169. 